\title{
An Experimental Study on Partial Replacement of Coarse Aggregate by Iron Slag with Polypropylyne Fiber
}

\author{
P. Vignesh Kumar ${ }^{1}$, R. Ranjith Kumar ${ }^{2}$ \\ ${ }^{1}$ Student (M.E. Structural Engineering), JCT College of Engineering and Technology Pichanur Coimbatore \\ ${ }^{2}$ Assistant Professor of Civil Engineering, JCT College of Engineering and Technology Pichanur Coimbatore
}

\begin{abstract}
Iron slag an industrial waste by-product of steel industry. Basically it consists of aggregates which are bonded together by cement and water. Old scrap is collected after a use cycle, either separately or mixed, and it is often contaminated to a certain degree, depending highly on its origin and the collection systems used. Since the lifetime of many metal products can be longer than 10 years and sometimes longer than 50years, for instance products for building and construction, there is an accumulation of metal in use since the beginning of the industry. As the disposal of this waste is posing serious problem to the environment it is better to use this type of material in making concrete so that a waste material can be disposed off by cleaner technology. This methodology will also prevent degradation in environment. Iron slag which is generated in large quantities as waste is hardly being used in the preparation of concrete. Special quality control procedures may be required to address the lack of consistency in some properties such as gradation, specific gravity, and absorption found. Control concrete with $25 \%$ and $30 \%, 35 \%$ coarse aggregate and1\% of polypropylene fibre replacement with Iron slag were made. Blast furnace slag is mildly alkaline and exhibits a pH in solution in the range of 8 to 10. Although blast furnace slag contains a small component of elemental sulphur (1 to 2 percent), the leach ate tends to be slightly alkaline and does not present a corrosion risk. Concrete obtained by this method may have more self weight than the conventional concrete, but it is expected to provide more strength than the conventional concrete
\end{abstract}

Keywords: Iron slag, Polypropylene Fiber, Compressive strength, Split tensile strength, Flexural strength

\section{Introduction}

Iron slag is a by- product of iron and steel making process. Steel cannot be prepared in the Basic Oxygen Furnace (BOF) or in an Electric Arc Furnace (EAF) without making its byproduct steel slag. There are many experimental work conducted to improve the properties of concrete by putting new materials, whether it is natural resources or recycle materials or synthetic materials in the concrete mix. If the waste cannot be disposed properly it will lead to social and environmental problem. The high cost of conventional building materials is a major factor affecting building construction. This has necessitated research into alternative materials of construction. . The disposal of whole iron slags into used as landfills. To avoid this, so many recycling methods for iron slag are carried according to the need. From this, one of process is to make the iron slag into small pieces and used in cement concrete. Different alternative waste materials and industrial by-products such as fly ash, bottom ash, recycled aggregates, foundry sand, china clay sand, crumb rubber, glass were replaced with natural aggregate and investigated the properties of the concretes. Apart from above mentioned waste materials and industrial by products, Iron slag can also be used as coarse aggregate in concrete. The growing concrete of resource depletion has challenge many engineers and researchers to seek and develop new materials for construction, this include the use of by-product and industrial waste in building construction. Many of these by products may serve as aggregate in concrete. With global economic recession coupled with the market inflationary trends, the constituent materials used for those structures have lead to a very high cost of construction. Hence researcher in material science and engineering are committed to having local materials to partially or fully replace these costly conventional materials. Numerous researches have been carried out in these regard as well as sustainability development, reduction in cost and the ability to produce high density concrete are added advantage of such materials. Concrete is one of the major building materials that can be delivered to a project site. Hence the overall cost of concrete production depends largely on the availability of the constituent.

\section{Materials Used}

\section{Cement}

Ordinary Portland cement of Grade 53 has been used in the study. Table 1 shows the physical characteristics of cement used, tested in accordance with IS: 4031-1988.

\section{Fine aggregates}

The fine aggregate used was locally available river sand without any organic impurities and conforming to IS: $383-$ 1970. The fine aggregate was tested for its physical requirements such as gradation, fineness modulus, specific gravity and bulk density and is shown in Table 2 .

\section{Coarse Aggregate}

The aggregate used in this project mainly of basalt rock which comes under normal weight category. The aggregates are locally available. $50 \%$ of the aggregate used are of 10-12 $\mathrm{mm}$ size and remaining $50 \%$ are of $20 \mathrm{~mm}$ size. The coarse aggregate was also tested for various properties like specific gravity test, fineness modulus, crushing strength test, water absorption test to check their suitability for the experiment 


\section{International Journal of Science and Research (IJSR) \\ ISSN (Online): 2319-7064 \\ Index Copernicus Value (2013): 6.14 | Impact Factor (2014): 5.611}

\section{Iron slag}

In a blast furnace, crude or pig iron is made by stripping the oxygen and other impurities from iron ore by means of hightemperature reactions with reducing agents (mainly carbon) and fluxes. The impurities and fluxing agents combine to form a liquid silicate melt called iron or blast furnace slag.
Preparation of Iron Slag Aggregate

Iron slag is collected from industrial. It is dried until the moisture is reduced. Then it is manually crushed. i. e. broken into small pieces with hammer or stone after that it is crushed using mechanical process. The iron slag aggregate are sieved. The size of iron slag aggregate taken is $20 \mathrm{~mm}$

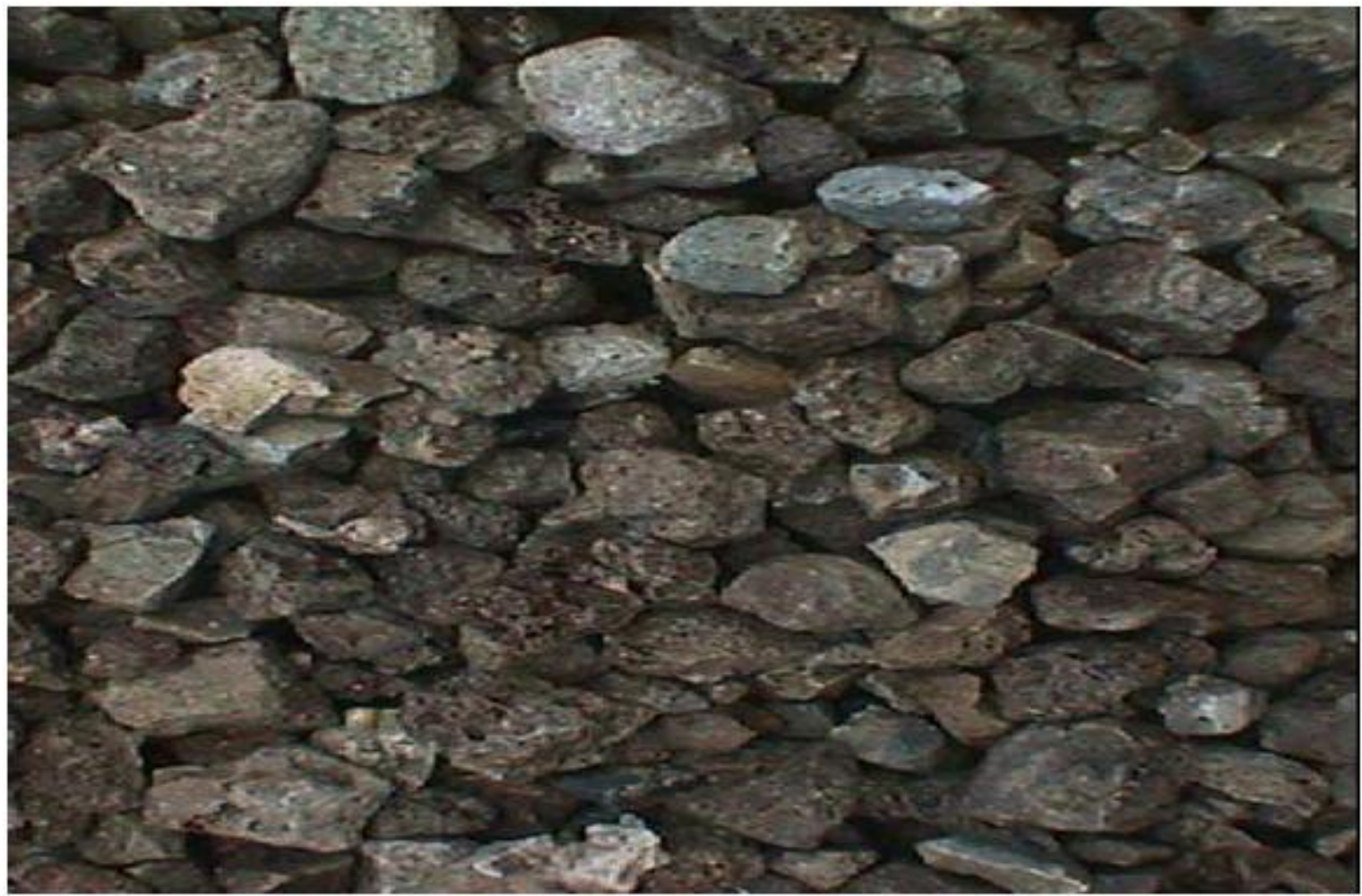

Figure 1: Iron slag

Table 1: Chemical Constituents in Blast Furnace Slag

\begin{tabular}{|c|c|}
\hline Constituent & Weight Percent \\
\hline Lime & 32 to 45 \\
\hline Magnesia & 5 to 15 \\
\hline Silica (Si02) & 32 to 42 \\
\hline Alumina(Al203) & 7 to 16 \\
\hline Sulfur (S) & 1 to 2 \\
\hline Iron Oxide (Fe203) & 0.1 to 1.5 \\
\hline Manganese Oxide & 0.2 to 1.0 \\
\hline
\end{tabular}

\section{Polypropylene Fiber}

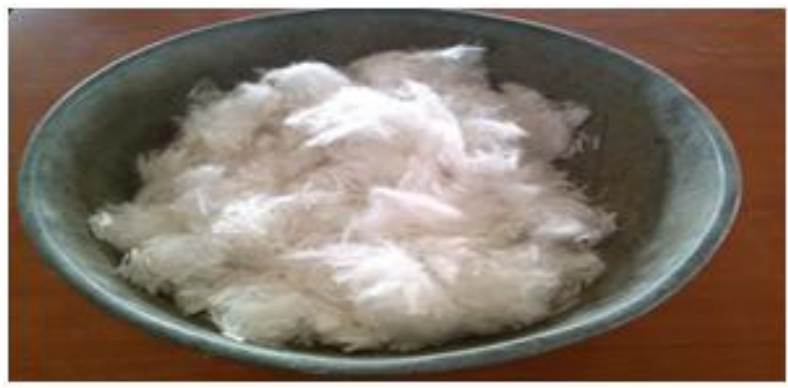

Figure 2: Polypropylene fibre

Polypropylene fibre used in this experimental investigation was manufactured by Reliance Industry Limited (RIL) in the brand name Recron 3s and its properties are given in table
Table 2: Properties of polypropylene fiber

\begin{tabular}{|c|c|}
\hline Property & Value \\
\hline Tensile Strength & $4.84 \mathrm{G} \mathrm{Pa}$ \\
\hline Elastic modulus & $89 \mathrm{G} \mathrm{Pa}$ \\
\hline Elongation at break & $3.15 \%$ \\
\hline Density & $2.7 \mathrm{~g} / \mathrm{cm}^{3}$ \\
\hline Composition & $45-55 \% \mathrm{SiO} 2,2-6 \%$ alkalis \\
& $5-14 \% \mathrm{Fe} \mathrm{O}, 14 \% \mathrm{Al} 2 \mathrm{O} 3,0.5-2 \% \mathrm{TiO} 2$ \\
\hline Specific gravity & $0.91 \mathrm{~g} / \mathrm{cm} 3$ \\
\hline Cut length & $12 \mathrm{~mm}$ \\
\hline Width crossing & $\mathrm{Circular}$ \\
\hline Melting point & $250{ }^{\circ} \mathrm{C}$ \\
\hline Water absorption & 0 \\
\hline
\end{tabular}

\section{Water}

In the present investigation, potable water was used as said IS 456-2000 for the plain and Reinforcement.

\section{Concrete Mix Design}

Conventional concrete mix of grade M30 has been designed based on Indian Standard Recommended Guidelines IS: 10262-2009. The proportion and quantities of various materials for the concrete mix have been presented in Table For SCC of grade M30 the mix design was done based on Nan Su approach [2001]. The mix proportion is given in Table 8 for different aggregate sizes. 


\section{International Journal of Science and Research (IJSR) \\ ISSN (Online): 2319-7064}

Index Copernicus Value (2013): 6.14 | Impact Factor (2014): 5.611

Table 3: Quantity of mix proportion

\begin{tabular}{|c|c|c|c|}
\hline Water & Cement & Fine Aggregate & Coarse Aggregate \\
\hline 197 & $437.7 \mathrm{~kg}$ & $699.31 \mathrm{~kg}$ & $1044.58 \mathrm{~kg}$ \\
\hline 0.450 & 1 & 1.59 & 2.38 \\
\hline
\end{tabular}

\section{Material Test Results}

\section{Cement}

Table 4 Physical Properties of Cement

\begin{tabular}{|c|c|c|}
\hline S. No & Property & Value \\
\hline 1 & Normal Consistency & $34 \%$ \\
\hline 2 & Initial Setting time & 35 minutes \\
\hline 3 & Specific Gravity of cement & 3.15 \\
\hline 4 & Fineness of cement by sieve & $2 \%$ \\
\hline
\end{tabular}

\section{Coarse Aggregate}

Table 5: Physical Property Of Coarse Aggregate

\begin{tabular}{|c|c|c|}
\hline S. No & Property & Value \\
\hline 1. & Specific gravity & 2.663 \\
\hline 2. & Water absorption & $0.6 \%$ \\
\hline 3. & Flakiness index & $87.44 \%$ \\
\hline 4. & Elongation index & $7.2 \%$ \\
\hline 5. & Impact strength & $9.3 \%$ \\
\hline 6. & Crushing strength & $2.95 \%$ \\
\hline
\end{tabular}

Fine Aggregate

Table 6: Physical Properties of Fine Aggregate

\begin{tabular}{|c|c|c|}
\hline S. No & Property & Value \\
\hline 1. & Fineness value & $3.60 \%$ \\
\hline 2. & Sieve test & Separate analyze are done \\
\hline 3. & Specific gravity & 2.74 \\
\hline
\end{tabular}

Table 7: Physical Property of Iron Slag

\begin{tabular}{|c|c|c|}
\hline S. No & Property & Value \\
\hline 1. & Specific gravity & $2.8 \%$ \\
\hline 2. & Water absorption & $1.05 \%$ \\
\hline 3. & Flankiness index & $53.90 \%$ \\
\hline 4. & Elongation index & 4.5 \\
\hline 5. & Impact strength & $8.3 \%$ \\
\hline 6. & Crushing strength & $2.95 \%$ \\
\hline
\end{tabular}

\section{Hardened Concrete}

Compressive strength, Split tensile strength and Flexural Strength were tested on Cubes, Cylinders and Prisms for conventional concrete, SCC and PFRSCC. The strength of concrete has been tested after 7, 14 and 28 days of normal curing. The test results are given in following figures.

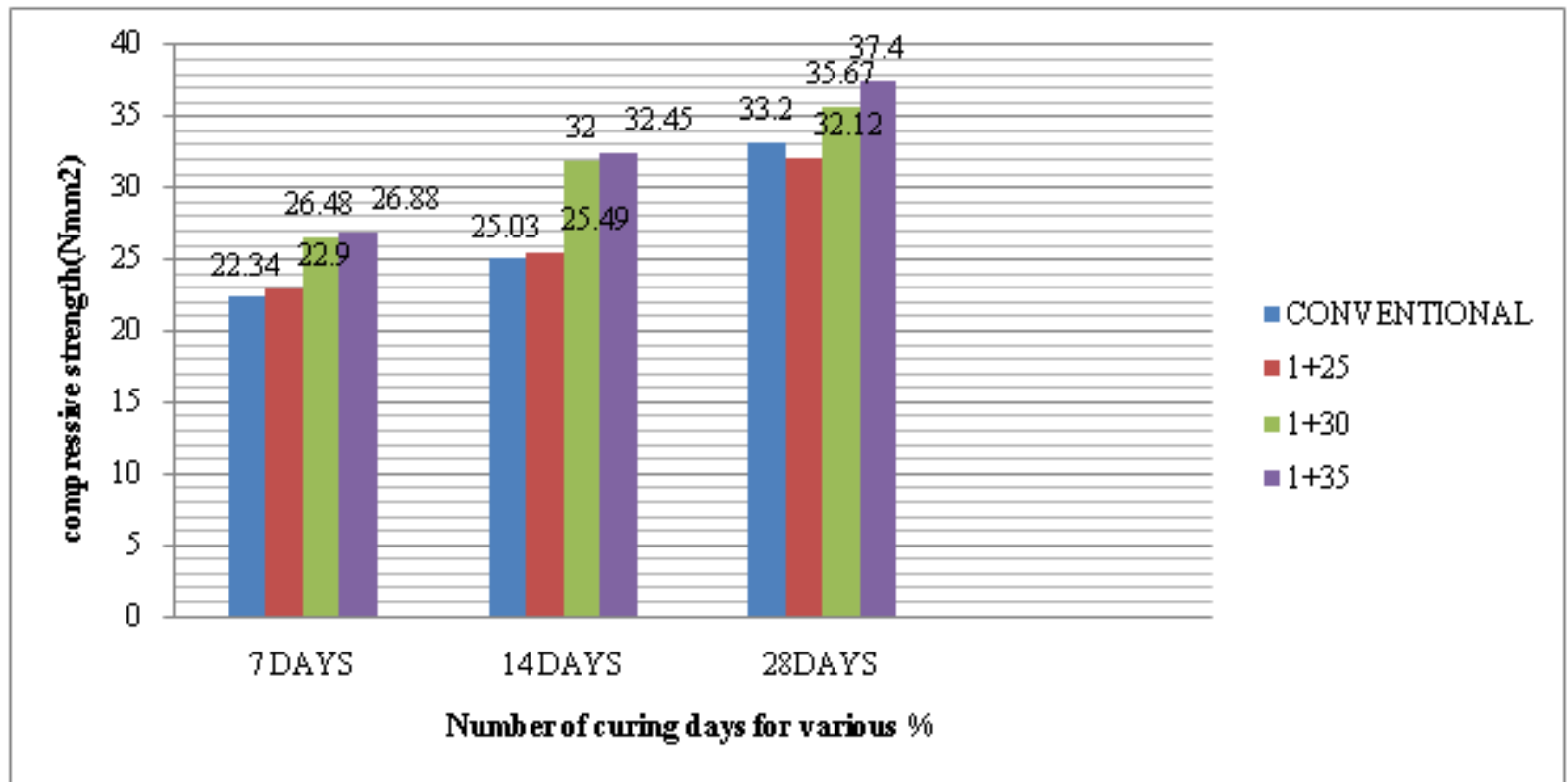

Figure 3: Compressive Strenth For M30 Grade 
International Journal of Science and Research (IJSR)

ISSN (Online): 2319-7064

Index Copernicus Value (2013): 6.14 | Impact Factor (2014): 5.611

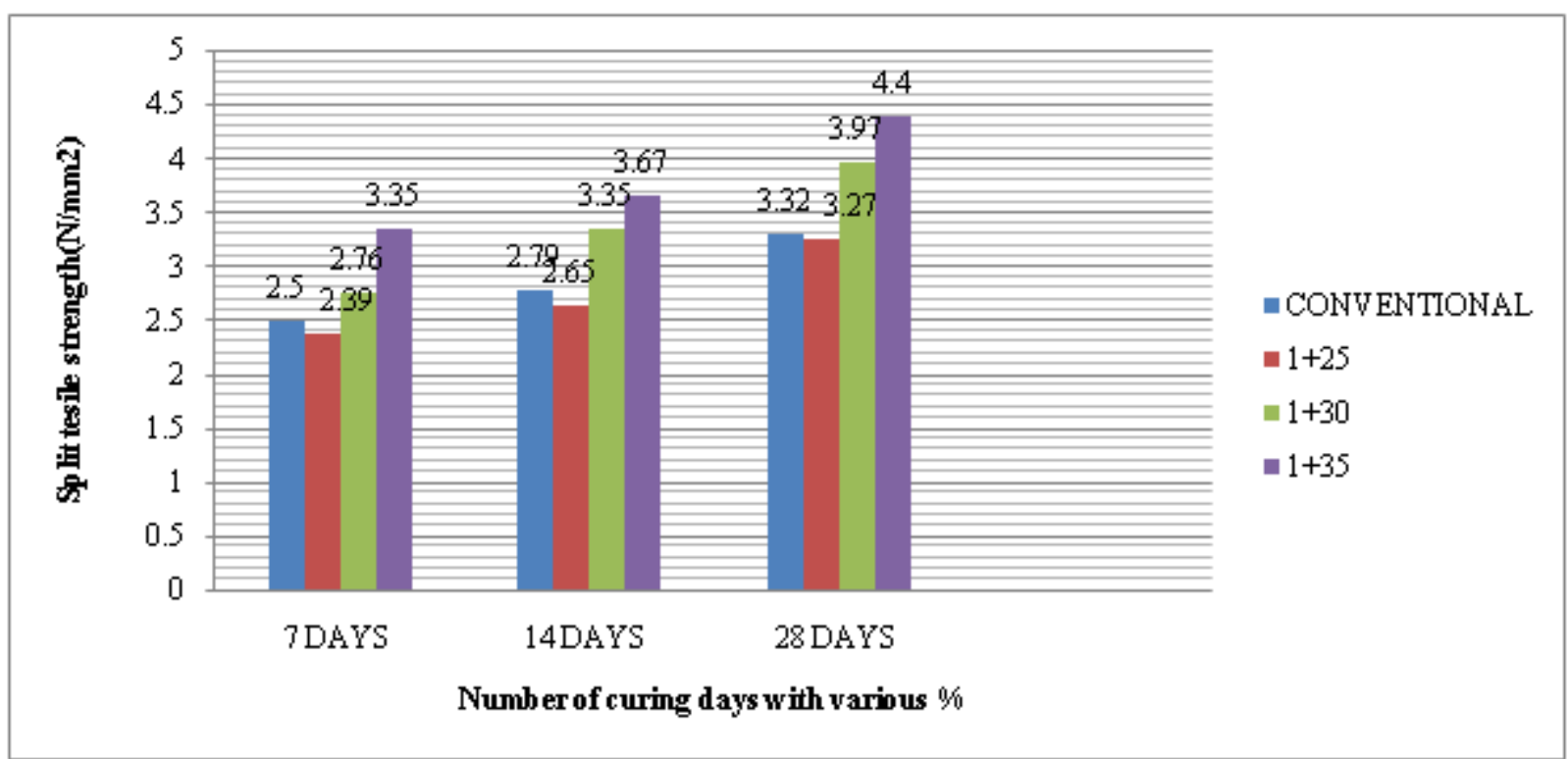

Figure 4: Split Tensile Strength For M30 Grade

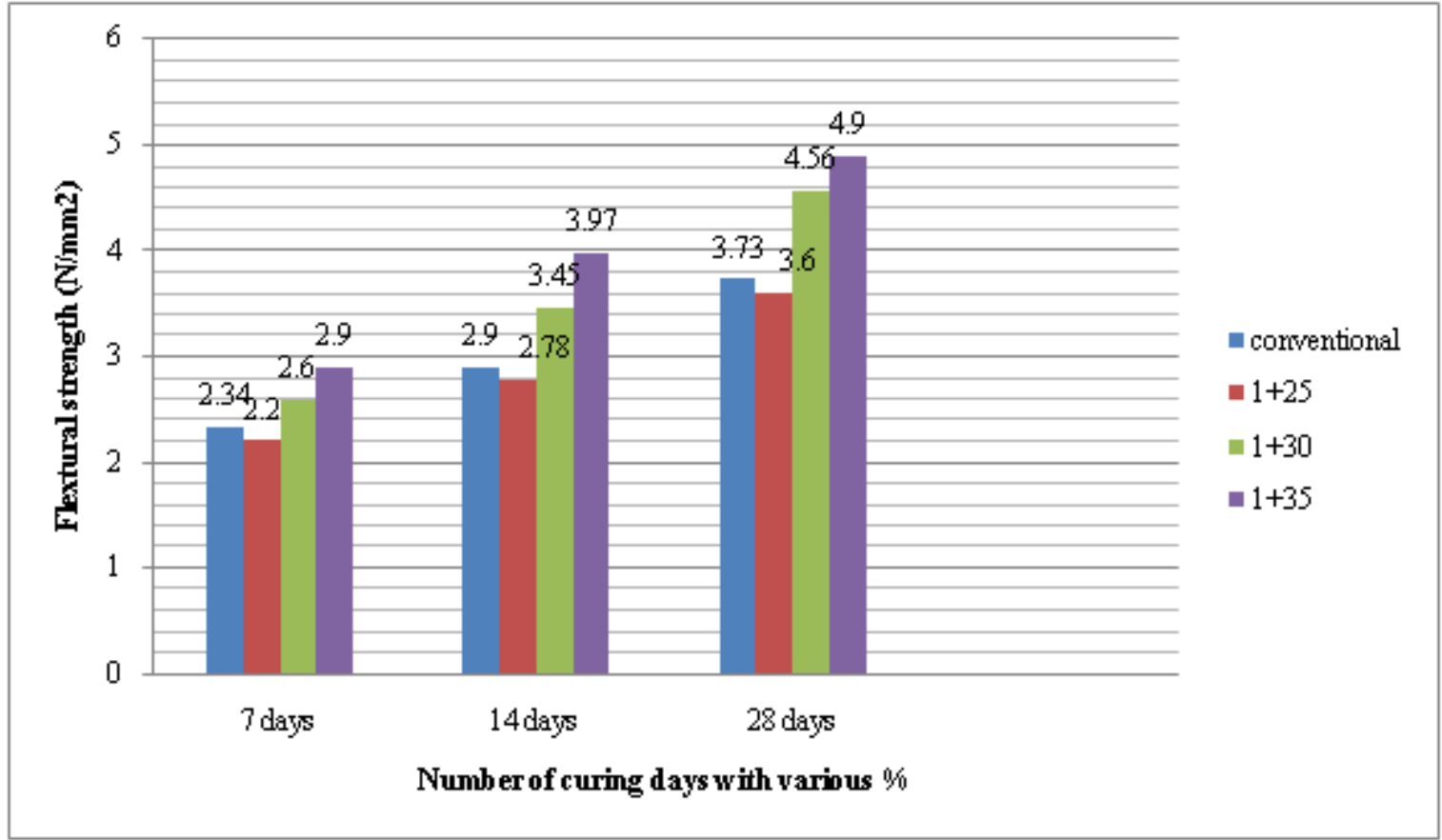

Figure 5: Flextural Strength for M30 Grade

\section{Conclusion}

The following conclusions are drawn from the study of partial replacement of coarse aggregate with iron slag in the cement concrete:

In this study of partial replacement of coarse aggregate with iron slag in the cement concrete have greater strength than the conventional concrete. As the self weight of this concrete is higher. The polypropylene fibres are free from water absorption. With improved understanding of the link between fibre characteristics and composite or structural performance.

In $25 \%$ iron slag used the compressive strength decreased $1 \%$ and split tensile strength also decreased.

- If the addition of $30 \%$ and $35 \%$ of the iron slag used. Increased compressive strength in concrete. The compressive strength of the concrete is increased 4\%and $5 \%$ compared then the conventional concrete.

- 30 and $35 \%$ of the addition of iron slag is $6 \%$ increased split tensile strength compared than conventional concrete.

- $30 \%$ and $35 \%$ the addition of iron slag replaced in concrete $6 \%$ is increased flexural strength compared than the conventional concrete.

\section{Scope for Further Work}

1) The simplified mix design methodology was presented may be extended to the more number of concrete strength ranges.

2) The investigations may be conducted with different mineral admixtures like Rice Husk Ash and Silica fume apart from fly ash and GGBS. 
3) The study may be extended to evaluate the durability properties of Polypropylene Fibre Reinforced Self Compaction Concrete

\section{References}

[1] Dhanasri K1, Kishore Kumar M2 Performance of Concrete by replacing Coarse Aggregate and Fine Aggregate with Blast Furnace Slag and Crusher Dust International Journal of Innovative Research in Science ,Engineering and Technology December 2013

[2] Mohammed Nadeem, Arun D. Pofale Utilization of Industrial Waste Slag as Aggregate in Concrete Applications by Adopting Taguchi's Approach for Optimization International Journal of Science and Research (IJSR) October 2014

[3] Mohammed Nadeem, Arun D. Pofale Utilization of Industrial Waste Slag as Aggregate in Concrete Applications by Adopting Taguchi's Approach for Optimization International Journal of Science and Research (IJSR) October 2014

[4] Khalid Raza1, Apoorv Singh2, R. D. Patel3 Strength Analysis Of Concrete By Using Iron Slag Asa Partial Replacement Of Normal Aggregate(Coarse) In concrete international journal of scientific \& engineering research, volume 4, issue 5, may 2013

[5] .K.G. Hiraskar And Chetan Patil Use Of Blast Furnace Slag Aggregate In Concrete International Journal Of Innovative Research In Science,Engineering And Technology December 2013

[6] Kolli.Ramujee Strength Properties Of Polypropylene Fiber Reinforced Concrete International Journal Of Advanced Engineering Technology January-March, 2012

[7] V.M. Sounthararajan1, Anshul Jain2, Abhishek Kumar Singh, S. Thirumurugan Evaluation Of Composite Polypropylene Fibre Reinforced Concrete/ International Journal Of Engineering And Technology (Ijet)

[8] Dr.T.Ch.Madhavi1, L.Swamy Raju2, Deepak Mathur Polypropylene Fiber Reinforced Concrete International Journal Of Emerging Technology And Advanced Engineering June 2014

[9] Mustapha Abdulhadi A Comparative Study Of Basalt And Polypropylene Fibers Reinforced Concrete On Compressive And Tensile Behavior International Journal Of Engineering Trends And Technology (IJETT) - Volume 9 Issue 6- March 2014

[10] IS 383: 1970," Specification for coarse and fine aggregate from source for concrete", Bureau of Indian Standards, New delhi.

[11] IS 516 : 2009," Hand book of concrete mix design", Bureau of Indian Standards, New delhi.

[12] IS 10262 : 1982," Specification for strength of concrete", Bureau of Indian Standards, New delhi.

[13] IS 12269 : 1987," Specification for 53 grade Ordinary Portland Cement" IS 2386 (Part I-VIII) - 1960, Indian Standards method of testing for concrete, (First revision), Bureau of Indian Standards, New Delhi. 